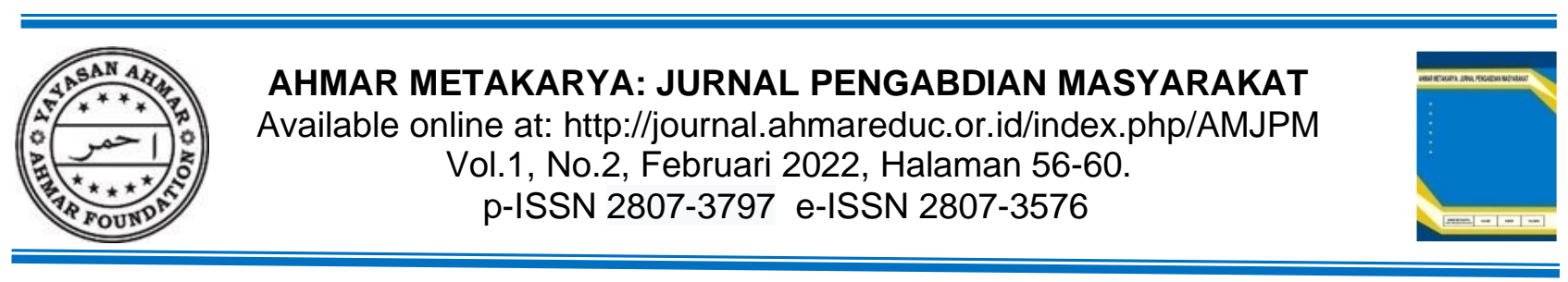

\title{
Upaya Peningkatan Pemahaman Ibu Hamil Tentang Kepatuhan Dalam Mengkonsumsi Tablet Fe
}

\author{
Gladeva Yugi Antari*, Ririn Supianti \\ Program Studi D-III Kebidanan, STIKES Griya Husada Sumbawa, Nusa Tenggara Barat, Indonesia \\ *E-mail: gladevaantari@gmail.com
}

Received: 7 September 2022

Accepted: 25 Februari 2022

Published: 28 Februari 2022

\begin{abstract}
Efforts to reduce the mortality rate of pregnant women still cannot be maximized due to the COVID-19 pandemic that has hit the world. The prevalence of anemia in pregnant women is still high both at the national level and in NTB. Complications that cause death in the mother, one of which is caused by bleeding. This bleeding can be caused by maternal conditions during pregnancy such as anemia. This anemia itself can be prevented by adherence to consuming Fe correctly. The purpose of this community service is to increase the knowledge of pregnant women about anemia as a prevention of the incidence of anemia in pregnant women so that it can have an impact on reducing mortality. The method in this service is to provide counseling about anemia in pregnant women and how to consume Fe correctly, which is carried out at the Moyo Hulu Health Center with a total of 11 pregnant women participating. Based on the results of the pretest and post-test conducted, it was found that there was an increase in knowledge and understanding of mothers about anemia and the benefits of Fe tablets. It is hoped that there will be changes in the behavior of pregnant women in caring for their pregnancy so that pregnancy complications such as anemia can be prevented by consuming Fe properly.
\end{abstract}

Keywords: Community Service, Pregnant Women, Anemia, Fe (Iron Tablets), Covid-19.

\begin{abstract}
Abstrak
Upaya penurunan angka kematian ibu hamil masih belum bisa maksimal dilakukan akibat pandemic covi-19 yang melanda dunia. Prevalensi anemia pada ibu hamil yang masih tinggi baik di tingkat nasional maupun di NTB. Komplikasi yang menyebabkan kematian pada ibu salah satunya disebabkan oleh adanya perdarahan. Perdarahan ini bisa disebabkan oleh kondisi ibu selama kehamilan seperti anemia. Anemia ini sendiri dapat dicegah dengan kepatuhan dalam mengkonsumsi Fe secara benar. Tujuan dari pengabdian kepada masyarakat ini adalah meningkatkan pengetahuan ibu hamil tentang anemia sebagai pencegahan kejadian anemia pada ibu hamil sehingga dapat berdampak menurunkan angka kematian. Metode dalam pengabdian ini adalah dengan memberikan penyuluhan mengenai anemia pada ibu hamil dan cara mengkonsumsi $\mathrm{Fe}$ yang benar, yang dilakukan di Puskesmas Moyo Hulu dengan jumlah peserta sebanyak 11 orang ibu hamil. Berdasarkkan hasil pre-test dan post-test yang dilakukan didapatkan hasil bahwa terdapat peningkatan pengetahuan dan pemaham ibu tentang anemia dan manfaat tabet Fe. Diharapkan adanya perubahan perilaku ibu hamill dalam merawat kehamilannya sehingga komplikasi kehamilan seperti anemia bisa dicegah dengan mengkonsumsi Fe dengan benar.
\end{abstract}

Kata Kunci: Pengabdian Kepada Masyarakat, Ibu Hamil, Anemia, Fe (Zat Besi), Covid-19. 
Antari, G. Y., \& Supianti, R. (2022). Upaya Peningkatan Pemahaman Ibu Hamil Tentang Kepatuhan Ibu Hamil Dalam Mengkonsumsi Tablet Fe. Ahmar Metakarya: Jurnal Pengabdian Masyarakat, 1 (2), 56-60.

\section{A. PENDAHULUAN}

Dunia sedang berada pada kondisi yang tidak baik dengan adanya pandemic COVID-19. Hal ini menyebabkan tidak maksimalnya penurunan angka kematian pada ibu hamil di dunia. Menurut data Bill \& Melinda Gates Foundation (2020) angka kematian ibu di dunia pada tahun 2019 mencapai 140/100.000 kelahiran hidup, sedangkan dikawasan Negara ASIA Tenggara pada tahun yang sama mencapai angka 197 /100.000 kelahiran hidup. Indonesia sebagai salah satu Negara di ASIA Tenggara memiliki angka kematian ibu sebesar 136/100.000 kelahiran hidup pada tahun 2019. Angka kematian ini jauh dari target SDG's yaitu sebesar 70/100.000 kelahiran hidup (Bill \& Melinda Gates Foundation, 2020)

Kematian pada ibu hamil sebesar $75 \%$ disebabkan oleh beberapa komplikasi seperti pendarahan hebat (kebanyakan pendarahan setelah melahirkan), infeksi (biasanya setelah melahirkan), tekanan darah tinggi selama kehamilan (pre-eklampsia dan eklampsia), komplikasi dari persalinan dan aborsi propokatus. Komplikasi lain yang menyebabkan kematian ibu hamil berhubungan dengan infeksi seperti malaria atau terkait dengan kondisi kronis seperti penyakit jantung atau diabetes (WHO 2019).

Salah satu penyebab perdarahan hebat pada ibu hamil adalah anemia. Anemia sebagai salah satu masalah gizi di Indonesia yang harus di tangani secara serius, terutama pada anemia gizi, Prevalensi anemia besi ibu hamil yang tinggi dapat disebabkan oleh tingkat kepatuhan minum tablet besi yang rendah (20-30\%) (Afrilia, E. M., \& Sari, H. 2018). Anemia pada ibu hamil disebabkan oleh kekurangan zat besi yang diperlukan untuk pembentukan hemoglobin yang disebut anemia defisiensi besi. Suplementasi tablet besi merupakan salah satu cara yang bermanfaat dalam mengatasi anemia. Suplementasi besi sudah lama diberikan secara rutin pada ibu hamil di puskesmas dan posyandu, akan tetapi sejauh ini hasil yang dicapai belum menggembirakan, terbukti dari prevalensi anemia pada ibu hamil yang masih tinggi baik di tingkat nasional maupun di NTB (Satriyandari, \& Hariyati, 2017, Dinas Kesehatan Provinsi NTB, 2021).

Menurut Manuaba, et al., (2019) kepatuhan ibu hamil mengkonsumsi tablet Fe dipengaruhi beberapa faktor salah satunya adalah pendidikan dan pengetahuan ibu hamil tentang anemia dan manfaat tablet Fe. Berdasarkan data Dinas Kesehatan Kabupaten Sumbawa tahun 2019 angka anemia tertinggi salah satunya berada diwilayah Puskesmas Moyo Hulu. Antari dan Nudhira melakukan penelitian mengenai faktor yang menyebabkan anemia di Puskesmas Moyo Hulu, mendapatkan bahwa pengetahuan ibu hamil trimester III kurang dan kepatuhan ibu hamil dalam mengkonsumsi Fe masih kurang dari 90 tablet (Antari \& Nudhira 2021).

Pengabdian Masyarakat dengan peningkatan pemahaman ibu merupakan cara untuk meningkatkan pengetahuan ibu hamil tentang anemia sebagai pencegahan kejadian anemia pada ibu hamil sehingga dapat berdampak menurunkan angka kematian. Kegiatan pengabdian masyarakat ini menerapkan protokol kesehatan untuk mencegah penyebaran covid-19, seperti menggunakan masker, menerapkan physical distancing. Berdasarkan pemaparan diatas oleh sebab itu tujuan dari dilaksanakannya pengabdian masyarakat ini adalah untuk memberikan pendidikan kesehatan kepada ibu hamil tentang anemia sebagai upaya pencegahan di wilayah kerja Puskesmas Moyo hulu.

\section{B. METODE DAN PELAKSANAAN}

Metode yang digunakan dalam pengabdian masyarakat ini adalah dengan memberikan edukasi kepada ibu hamil melalui penyuluhan menggunakan lembar balik tentang anemia dan manfaat tablet Fe. Peserta adalah ibu hamil pada wilayah kerja Puskesmas Moyo Hulu yang memiliki usia kehamilan pada trimester I, II dan III. Peserta yang hadir sebanyak 11 orang ibu hamil. Tahapanpengabdian ini, antara lain:

1) Tahap Persiapan

Tahap persiapan (pra planning) merupakan pembagian tugas, yaitu antara lain:

a. Mempersiapkan Ruangan / tempat penyuluhan yang berkoordinasi dengan pihak Puskesmas

b. Mempersiapkan para ibu hamil diwilayah kerja puskesmas, persiapan ibu hamil disesuaikan dengan mengikuti protokol kesehatan yaitu memakai masker, mencuci tangan, mengatur jarak, menjauhi kerumunan dan membatasi mobilisasi dan interaksi. 
c. Melakukan pendataan ibu hamil yang datang berkunjung.

d. Melakukan Pengukuran Suhu tubuh.

e. Membuat Pendokumentasian Kegiatan

2) Tahapan Pelaksanaan

Pelaksana pengabdian dilakukan oleh dosen bersama mahasiswa dalam memberikan penyuluhan tentang anemia dan manfaat tablet Fe pada ibu hamil. Kegiatan dilaksanakan selama 1 hari tepatnya pada hari Sabtu, tanggal 17Juli 2021.

3) Tahap Evaluasi

a. Tidak semua ibu hamil pada wilayah kerja Puskesmas Moyo Hulu hadir dalam kegiatan ini dikarenakan banyak ibu hamil berhalangan hadir pada saat kegiatan diselenggarakan. Setelah dilakukan pendataan diketahui bahwa ibu hamil yang hadir sebagian besar merupakan ibu primigravid sebanyak 8 orang $(73 \%)$ dan sisanya multigravid.

b. Peserta yang hadir sebelumnya diberikan pretest sebanyak 10 soal seputar anemia dan tablet $\mathrm{Fe}$, untuk mengetahui pemahaman ibu. Kemudian dilakukan penyuluhan oleh tim pelaksana menggunakan bahasa dan komunikasi yang komunikatif secara dua arah serta dibantu menggunakan lembar balik. Setelah dilakukan penyuluhan peserta diberikan posttest menggunakan soal yang sama dengan pretest untuk dapat mengukur peningkatan pemahaman ibu

c. Proses pelaksanaan kegiatan dalam pengabdian masyarakat ini berlangsung selama 1 hari ditanggal 17 Juli 2021 dari pukul 09.00 s/d 11.00 WITA sesuai jadwal yang telah direncanakan sebelumnya.

4) Hasil

Berdasakan hasil pre dan post-test pada tahap evaluasi, didapatkan bahwa terdapat peningkatan pengetahuan dan pemahaman tentang anemia dan manfaat tabet Fe pada peserta. Hal ini didasarkan pada hasil pre dan post-test yang diberikan selama kegiatan. Hasil pre-test didapatkan sebanyak 5 peserta (45\%) menjawab pertanyaan pada soal dengan benar sebanyak 6 soal keatas dan sisanya dibawahnya. Hasil post-test didapatkan bahwa sebanyak 11 peserta dapat menjawab soal post-test diatas 6 soal. Sehingga dapat disimpulkan bahwa terdapat peningkatan pengetahuan dan pemaham ibu tentang anemia dan manfaat tabet Fe.

\section{HASIL DAN PEMBAHASAN}

Kegiatan pengabdian pada masyarakat dilakukan dengan menerapkan protokol Kesehatan. Hal ini mendapat sambutan yang baik dari pemerintah desa dimana kegiatan yang telah dilaksanakan memiliki dampak yang positif pada masyarakat disekitaran wilayah kerja Puskesmas Moyo hulu untuk meningkatkan kesadaran tentang pentingnya mengkonsumsi Fe dan dampak buruk anemia pada saat hamil. Tujuan dari pengabdian ini untuk meningkatkan pengetahuan ibu hamil tentang anemia dan pentingnya konsumsi Fe antara lain penyebab, dampak, pencegahan dan manfaat serta cara mengkonsumsi Fe. Peserta yang mengikuti penyuluhan sebanyak 11 orang ibu hamil.

Kegiatan diawali dengan memberikan pre-test kepada peserta sebanyak 10 soal untuk mengetahui pemahaman ibu. Penyuluhan oleh tim pelaksana menggunakan lembar balik. Setelah dilakukan penyuluhan peserta diberikan post-test menggunakan soal yang sama dengan pretest untuk dapat mengukur peningkatan pemahaman ibu.

Berdasakan hasil pre dan post-test pada tahap evaluasi, didapatkan bahwa terdapat peningkatan pengetahuan dan pemahaman tentang anemia dan manfaat tabet Fe pada peserta. Hal ini didasarkan pada hasil pre dan post-test yang diberikan selama kegiatan. Hasil pre-test didapatkan sebanyak 5 peserta (45\%) menjawab pertanyaan pada soal dengan benar sebanyak 6 soal keatas dan sisanya dibawahnya. Hasil post-test didapatkan bahwa sebanyak 11 peserta dapat menjawab soal post-test diatas 6 soal. Sehingga dapat disimpulkan bahwa terdapat peningkatan pengetahuan dan pemaham ibu tentang anemia dan manfaat tabet Fe. 
Antari, G. Y., \& Supianti, R. (2022). Upaya Peningkatan Pemahaman Ibu Hamil Tentang Kepatuhan Ibu Hamil Dalam Mengkonsumsi Tablet Fe. Ahmar Metakarya: Jurnal Pengabdian Masyarakat, 1 (2), 56-60.

Menurut Manuaba, et al., (2019) kepatuhan ibu hamil mengkonsumsi tablet Fe dipengaruhi beberapa faktor salah satunya adalah pendidikan dan pengetahuan ibu hamil tentang anemia dan manfaat tablet Fe. Pengetahuan yang baik secara tidak langsung akan membentuk sikap ibu dalam merawat kehamilannya sehingga komplikasi kehamilan dapat dihindarkan.

Penelitian yang dilakukan untuk mengetahui efektifitas penyuluhan terhadap peningkatan pemahaman ibu hamil tentang anemia menunjukkan hasil bahwa terdapat terdapat peningkatan pengetahuan (Afrilia, \& Sari, 2018). Peningkatan dipengaruhi oleh faktor eksternal yaitu informasi, dengan mendapatkan informasi yang tepat salah satunya melalui penyuluhan. Informasi memiliki fungsi penting sebelum seseorang akan melakukan suatu tindakan bahkan peserta dapat diberi kesempatan untuk bertanya lebih lanjut. Informasi akan lebih memperluas pengetahuan.

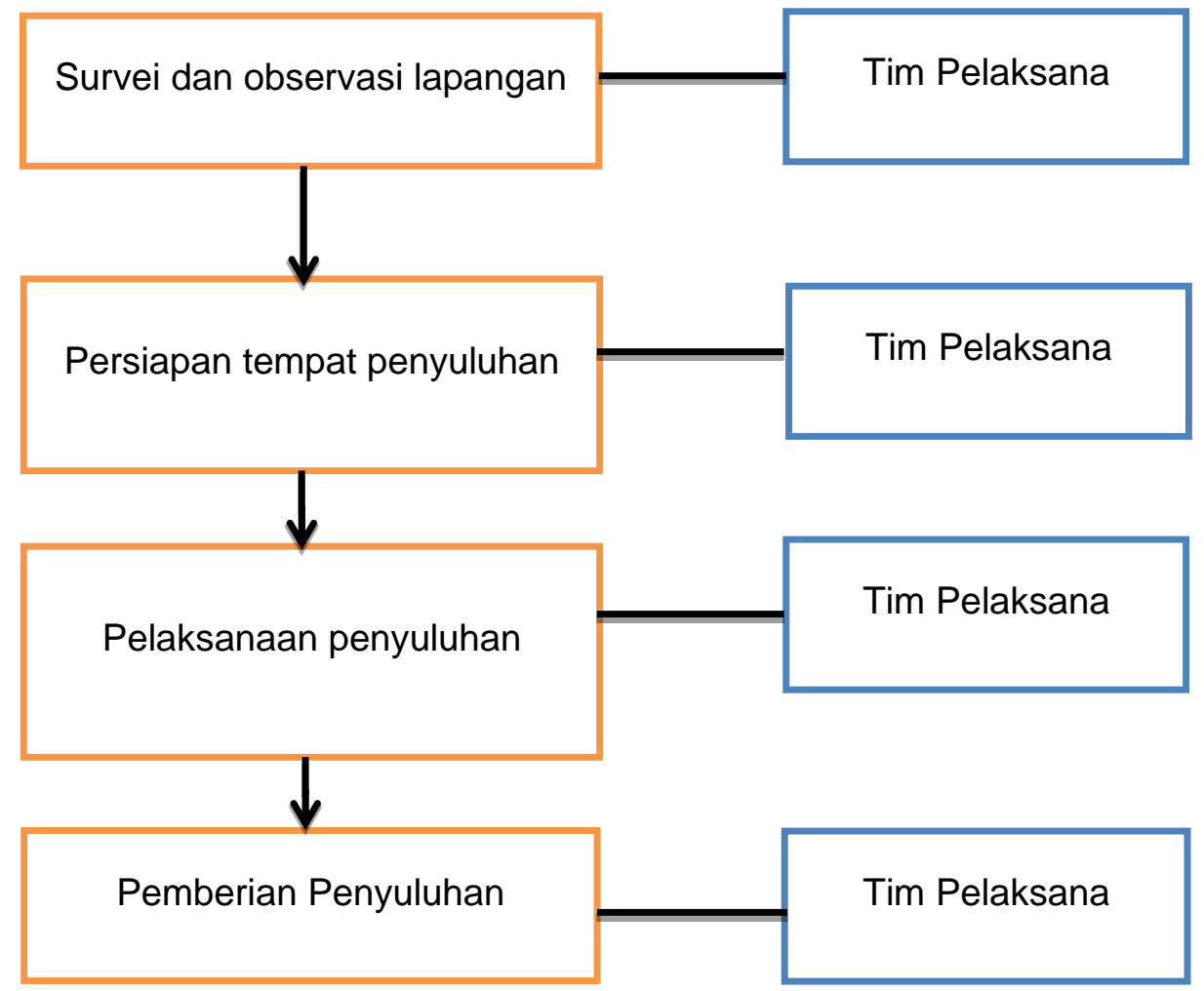

Diagram 1. Alur penyuluhan
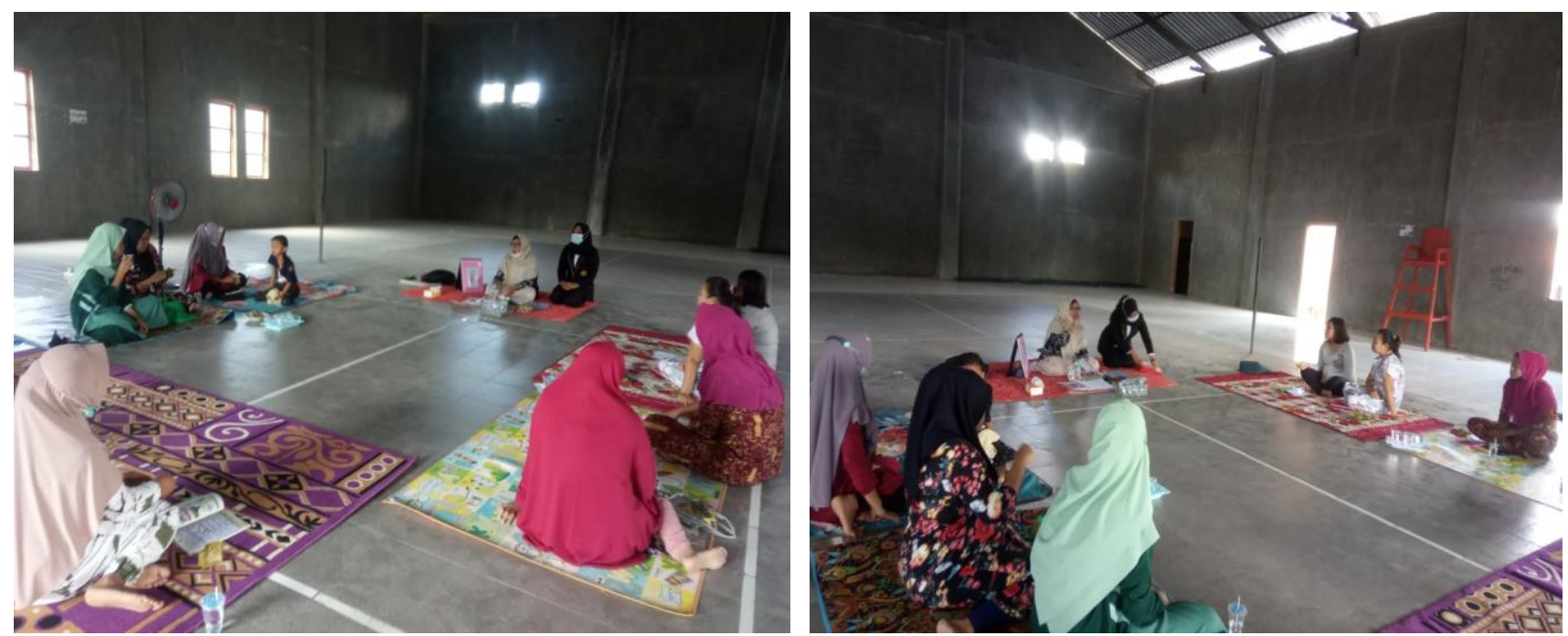

Gambar 1. Dokumentasi Pelaksanaan Penyuluhan 


\section{KESIMPULAN}

Kegiatan pengabdian pada masyarakat "Upaya Peningkatan Pemahaman Ibu Hamil Tentang Kepatuhan Ibu Hamil Dalam Mengkonsumsi Tablet Fe" berjalan lancar dan diikuti dengan antusias oleh para ibu hamill sehingga dapat disimpulkan hasil penyuluhan dari seluruh peserta memahami mengenai anemia dan cara mengkonsumsi $\mathrm{Fe}$ dengan benar. Kegiatan ini menerapkan protokol kesehatan sehingga semua orang bisa berkontribusi menjaga kesehatan. Proses pelaksanaan pengabdian masyarakat berjalan lancar dan tidak ada kendala yang berarti. Selanjutnyadiharapkan adanya perubahan perilaku ibu hamill dalam merawat kehamilannya sehingga komplikasi kehamilan seperti anemia bisa dicegah dengan mengkonsumsi Fe dengan benar.

\section{UCAPAN TERIMA KASIH}

Ucapan terima kasih yang sebesar-besarnya kami sampaikan kepada Kepala Puskesmas Moyo Hulu dan bidan Koordinator yang telah memberikan izin dan dukungan terhadap pelaksanaan kegiatan. STIKES Griya Husada Sumbawa yang telah memberikan dukungan fasilitas terhadap pelaksanaan kegiatan Penyuluhan ini.

\section{DAFTAR PUSTAKA}

Afrilia, E. M., \& Sari, H. (2018). Hubungan Metode Penyuluhan Small Group Discussion (SGD) Dengan Tingkat Pengetahuan Anemia Pada Ibu Hamil Di Rumah Bersalin Gebang Medika Kota Tangerang. Jurnal JKFT, 3(1), 79-85.

Antari, G. Y., \& Nudhira, U. (2021). Analisis Faktor Risiko Anemia Pada Ibu Hamil Trimester III: Analisis Faktor Risiko Anemia Pada Ibu Hamil Trimester III. Ahmar Metastasis Health Journal, 1(3), 85-91.

Bill \& Melinda Gates Foundation. (2020). SDG target: Reduce the global maternal mortality ratio to less than 70 per 100,000 live births. gates foundation. Bill \& Melinda Gates Foundation.

Dinas Kesehatan Provinsi NTB. (2021). Profil Kesehatan Kota Sumbawa Tahun 2021. Nusa Tenggara Barat: Dinas Kesehatan Provinsi NTB.

Manuaba, S. K. D. S., Manuaba, C., Manuaba, F., \& Manuaba, I. B. G. (2019). Buku ajar ginekologi untuk mahasiswa kebidanan. Jakarta: EGC.

Satriyandari, Y., \& Hariyati, N. R. (2017). Faktor-faktor yang mempengaruhi kejadian perdarahan postpartum. JHeS (Journal of Health Studies), 1(1), 49-64.

WHO. (2019). Maternal Mortality. Geneva: World Health Organization. Available on https://www.who.int/news-room/fact-sheets/detail/maternal-mortality 